\title{
Role of the University in city agglomerations sustainable development
}

\author{
Sergey Kortov $^{1}$, Alexandra Terlyga ${ }^{1 \mathrm{a}}$, and Nadezhda Terlyga ${ }^{1}$ \\ ${ }^{1}$ Ural Federal University named after the first President of Russia B.N. Yeltsin, 620002, \\ Yekaterinburg, Russia
}

\begin{abstract}
It is shown that existing models of sustainable cities and entrepreneurial universities development do not take mutual influence into consideration. In this work there are offered approaches to the models of interconnected cities and universities on the basis of the principle «wonwon», principle of scale accountancy and dynamics of university activity results influence on a sustainable city development is validated, systems of conjugated markers and indicators are elaborated.
\end{abstract}

\section{Introduction}

Chain of crisis phenomena shaking global economics during the last 15 years, accelerated development of technics and technologies, change of social processes tell about the growth of economic formation which is more and more often called as postindustrial society. The brightest characteristic of a new civilization development period is given by E. Toffler [1], who characterized it as "The Third Wave": "The Third Wave brings with it a genuinely new way of life based on diversified, renewable energy sources; on methods of production that make most factory assembly lines obsolete; on a novel institution that might be called the "electronic cottage"; on and on radically changed schools and corporations of the future». Transition to a new formation goes through acute aggravation of demographic ecological, technological, social cultural problems of society. One of the answers to these challenges is the idea of «sustainable development», which was first stated in 1987 in a form of the concept in UNO Committee report on environment and development [2] and it is performed as 27 principles of sustainable development in 1992 in UNO Declaration on environment and development [3].

At its core the concept of sustainable development has an anthropocentric character, defining actions in three main directions: ecological, social and economic. In Russia the concept of sustainable development was accepted in the form of Decree by the President of the RF «Main statements of RF strategies on environmental protection and sustainable development» [4]. Principles of sustainable development are successfully applied to elaborate strategic documents for the countries, separate territories and cities [57], to implement the development programs management tools are intensively worked out. It includes as a rule structured lists of indicators for strategic and operating planning and responsivity [8-10].

\footnotetext{
a Corresponding author: sterlyga@gmail.com
} 
In conditions of postindustrial society special role is played by knowledge as the source of unique competitive advantages for economical agents, territories and states [11]. In this case the role of universities as generators of knowledge, human capital assets and key elements of national innovation systems rises sharply. Transformation of universities from «cathedral of science» into a significant factor of competitive struggle on a global level is reflected in the concept of entrepreneurial university $[12,13]$.

From the viewpoint of economic model the University of Entrepreneurial Type is a source of competitive growth, incomes and taxes flow, but not a center of state and business expenditures for science and education. University presence in the area must be a driver of its social economic development. In the work [14] there are 4 directions of transformation offered for entrepreneurial university. They are connected with the availability of competitive development strategies, entrepreneurial type of university management, formation of students and teachers' entrepreneurial culture, income sources diversification. As a matter of fact we are talking about presence of entrepreneurial university strategy connected with commercialization of its key competences in education, scientific research, innovation products and services, providing services not only from the vendor but also from the integrator of large-scale development projects for business, state and society. This task is stated in the definition of «the third mission», in the framework of which universities become «active participants of economic and cultural processes development; convert to organizations closely connected with industry and society as a whole» [15].

Analyzing the systems of indicators which characterize universities entrepreneurial potential, performed in a series of works $[16,17]$ shows that they are focused mainly on revealing inner factors of entrepreneurial medium development though a detailed analysis of university activity results influence on economics and society is absent.

Historical way of universities development shows that they are predominantly localized in city environment. Nevertheless in sustainable cities development concepts and strategies universities are positioned in their classical role only as a source to get a higher education for population. On the other hand entrepreneurial universities are basically aimed to achieve competitiveness in global markets and little attention is paid to the tasks of local territories and cities development. To some extent university influence on social-economic territory development happens automatically proceeding from natural «congruence» of the university as a part of the city. Although efficiency growth of entrepreneurial university as the city development driver requires transition to strategic management, where elaboration of city and university sustainable development inclusive model is needed. The aim of the present work is formation of approaches to create associated indicative models of city and entrepreneurial university sustainable development.

\section{Analysis of approaches for measurement of city and entrepreneurial university sustainable development}

To assess sustainable cities development mainly an indicative approach is used. It is based either on indicators offered by committee on sustainable UNO development either on authorial concept of social-economic development strategies vendors (see, for example, [7]).

In RF the system of sustainable development indicators is elaborated [18], it includes 4 groups, 18 subgroups and 132 indicators:

- social indicators (antipoverty activity, demography, health protection, education, transportation);

- economic indicators (revenues, consumption, finance); 
- ecological indicators (water, land and other resources, waste, atmosphere);

- institutes (presence of sustainable development strategy and population involvement in its implementation).

For rating score of cities sustainable development indicators systems made by ranking agencies are used. In McKinsey model [19] 5 directions, 18 factors and 18 indicators are performed:

- main needs of the population (water supply, accommodation, health protection, education;

- resources utilization efficiency (power, water, waste, industrial load);

- environment cleanness (pollution, purification, waste recycling);

- city infrastructure (transportation, population density, planting, buildings power efficiency;

- focus on sustainable future development (investments to environmental protection and ecologically clean work places).

In the rating of sustainable cities development, worked out by the company SGM [20] there are 4 groups which include 31 indicators (table 1):

- demography and population;

- social infrastructure;

- city infrastructure;

- economic development;

- ecology.

Analysis of sustainable development indicators system shows that universities are present in capacity of social subsystem element only in the model of SGM company (number of higher education establishment students for 10000 inhabitants). In all other models attention is focused on secondary education availability. At this rate the role of universities as drivers of sustainable cities development in majority of existing models is not reflected, although expectations connected with them are present in strategies of the Russian Federation regions social-economic development (see, for example [21]).

Let us consider systems of entrepreneurial universities development indicators. Most of the entrepreneurial universities models are founded on 5 principles by B. Clark. According to this work [22] in the frame of entrepreneurial universities research in Europe the model including 7 branches was used. These branches are:

- leadership and management;

- organizational potential, people, inducements;

- development of entrepreneurship in teaching and knowledge mastering;

- development possibilities for entrepreneurs;

- collaboration between university and business;

- international communications;

- level of university influence on external environment development.

In the work [16] in the frame of Russian universities research entrepreneurial potential modified model was used [22], which consists 6 characteristics groups.

\section{Strategy:}

- understanding of entrepreneurship development as a strategic aim of the higher education establishment;

- entrepreneurship activity growth support;

- inducements and awards for the teachers and researchers who actively support students' entrepreneurship.

\section{Finance resources:}

- long-term financial support of student enterprises as an approved part of university budget; 
- self-sufficiency of the university in the sphere of inner entrepreneurship support.

\section{Human resources}

- higher-education teaching personnel career enrolment and development with consideration of stance on entrepreneurship, presence of corresponding behavior and experience and also entrepreneurship activity support;

- development of human resources necessary for initial support of entrepreneurship projects lead by students and employees.

\section{Entrepreneurship and start ups support}

- presence of special entrepreneurship support infrastructure, conditions for business-hatching in campus or help in providing access to external objects;

- close collaboration with development institutes;

- integration of entrepreneurship education and support processes;

- including the university to the channels of access to private financing;

- mentoring from the viewpoint of teachers and entrepreneurs;

- integration of entrepreneurship support processes inside and outside.

\section{Entrepreneurship education}

- including entrepreneurship education in curriculum programs;

- wide offering of different forms of fast and effective education;

- creative methods of teaching, students and post-graduate students requirement accountability;

- dividing offers for burgeoning entrepreneurs and owners of growing business;

- students and graduates business support as a key component of education;

- integration into entrepreneurship training the results and research of its condition and growth.

\section{Assessment}

- regular inventory counts and entrepreneurship activity efficiency audit;

- formalized assessment of entrepreneurship activity, which includes long term monitoring of graduates entrepreneurship activity development.

As it is seen from the described approaches to the entrepreneurial university assessment, the main focus is on the entrepreneurship training and students and teachers entrepreneurial activity support which is expressed in creation and development of small enterprises on the basis of university elaborations. In a wider understanding on entrepreneurial strategy, offered in work [14], it is offered to assess entrepreneurial behavior as strive for key competences commercialization not only in the innovations sphere but also in education and scientific research.

Analysis of main assessment models of university entrepreneurial strategy shows that university is observed as an open system collaborating with external environment via results of its activity and influencing on it in a significant way. During the analysis of external environment development in the work [22] it is assessed how university entrepreneurial activity influenced on its surrounding and graduates, in the work [16] it is recommended to lead regular monitoring of graduates entrepreneurial activity. While evaluating the universities entrepreneurial potential the main is an expert method realized via target groups questionnaire with further results processing with the help of grade-rating assessment. In Russia an indicative method of entrepreneurial potential assessment is almost impractical, because entrepreneurial universities activity is weakly reflected in governmental system of their efficiency monitoring indicators. There is an interesting entrepreneurial and innovation universities activity level rate assessment model by Interfax agency [24], where 7 indicative markers are included:

1. Innovation entrepreneurship development level in higher educational establishment.

2. Volumes of patents network (national and international), supported by higher educational establishment by the end of 2014 . 
3. Participation of higher educational establishment in technological platforms development, in Programs of high-technological companies' innovation development.

4. Participation of higher education establishment in technological entrepreneurship development programs.

5. Educational programs (mainstream and supplementary education) performed by higher educational establishments in the sphere of entrepreneurship.

6. Volume of economic-contractual works in budget of higher educational establishment in 2014.

7. Participation of academic staff and learners of the higher educational establishment in objects of innovation infrastructure.

Ranking is performed via questionnaires (expert assessments) and application of state statistics data (indicative rates).

As it is seen from provided analysis, entrepreneurial universities are aimed to measurement of it influence on surrounding although development of the city and the territory as a life environment are not emphasized as a priority strategy in entrepreneurial university indicators system. Unfortunately, neither cities nor universities witness each other as natural partners who create competitive advantages for each other in case of elaboration and realization of congruent strategies of sustainable development. Working out a mutually connected system of university and city stable development is an important task, which solution will allow assessing the degree of mutual influence and compound documents of strategic character defining forms, mechanisms and results of such collaboration.

\section{Opportunities for creating of stable city and entrepreneurial university development congruent indicative models}

In this work the analysis of activity results congruency of entrepreneurial university on main cities stable development indicators was performed. As a basis the model offered in work [20] was taken, it is performed in table 1. The authors led a qualitative expert evaluation of university activity influence on a current indicators level as well as on their alterations rates. Assessment was made on the example of Ural Federal University (UrFU has more than 30 thousand students and 7 thousand employees, $9^{\text {th }}$ place among the universities of Russia according to the Interfax ranking «Innovations and entrepreneurship» in 2014) on corresponding indicators of Ekaterinburg. For assessment the following scale was used $(0$ - influence is absent, 1 - weak influence, 2 - average influence, 3 - strong influence). Near indicators in table 1 explanation on UrFU activity results indicator influence are given. Average values of UrFU on current indicators condition and rates of their alteration comprise 1.29/1.51. The greatest impact is made by university on education system development and city economics. From table 1 it is seen that the following list of indicators reflects not all the opportunities of university influence on the city environment. It is suggested to update the model with 3 new groups of indicators:

- development of small and medium businesses (share of small and medium enterprises (SME), volume of products issued by SME on the unit of economically active population (EAP));

- innovation activity of enterprises (share of innovation - active enterprises, share of innovation production in manufacturing volume, level of new technologies application in goods and services production);

- youth policy (relative share of employed youth, level of youth access to entrepreneurship, level of youth activity in healthy way of life and ecological initiatives); 
Assessment of the offered indicators influence in the system of table 1 increases correlation of university activity results influence on stable city development up to $1,53 / 1,90$. Further indicators system development for the cities in the context of collaboration with the university will allow shaping congruent pictures of competitiveness, by the reference to a principle «won-won».

Table 1. Entrepreneurial university influence on sustainable city development indicators (on example of UrFU and city of Ekaterinburg)

\begin{tabular}{|c|c|c|c|}
\hline & $\begin{array}{l}\text { Influence on present } \\
\text { value/on themes }\end{array}$ & \multicolumn{2}{|c|}{ List of RF cities stable development indicators } \\
\hline \multirow{19}{*}{ 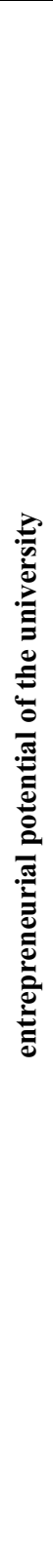 } & $\begin{array}{l}\text { 1/1 (birth rate of students } \\
\text { and employees) }\end{array}$ & \multirow{3}{*}{ Demography } & Coefficient os natural increase, $\%$ \\
\hline & $\begin{array}{l}\text { 2/3 (acceptance of foreign } \\
\text { and nonresident students) }\end{array}$ & & Coefficient of migration increase, $\%$ \\
\hline & $2 / 3$ (middle-age decrease) & & Demographic load, \% \\
\hline & $\begin{array}{l}\text { 1/1 (presence of policlinic, } \\
\text { UrFU) }\end{array}$ & \multirow{4}{*}{ Medicine } & $\begin{array}{c}\text { Number of doctors per } 10000 \\
\text { of population, } \%\end{array}$ \\
\hline & $\begin{array}{l}\text { 1/1 (presence of policlinic, } \\
\text { UrFU) }\end{array}$ & & $\begin{array}{l}\text { Number of mid-level health professionals } \\
\text { per } 10000 \text { of population, } \%\end{array}$ \\
\hline & $0 / 0$ & & $\begin{array}{c}\text { Number of beds at in-patient facilities per } \\
10000 \text { of population, } \%\end{array}$ \\
\hline & $\begin{array}{c}\text { 1/1 (presence of policlinic, } \\
\text { UrFU) }\end{array}$ & & $\begin{array}{c}\text { Capacity of outpatient departments per } \\
10000 \text { of population, }\end{array}$ \\
\hline & $\begin{array}{l}1 / 1 \text { (availability } \\
\text { of kindergarden by } \\
\text { the university) }\end{array}$ & \multirow{3}{*}{ Education } & $\begin{array}{l}\text { Number in need of attending pre-school } \\
\text { institutions as regards places in them, \% }\end{array}$ \\
\hline & $\begin{array}{l}1 / 1 \text { (presence of secondary } \\
\text { specialized college at } \\
\text { the university) }\end{array}$ & & $\begin{array}{l}\text { Number of secondary specialized college } \\
\text { students per } 10000 \text { of population, } \%\end{array}$ \\
\hline & $\begin{array}{c}4 / 4 \text { (more than } 30 \% \\
\text { of students } \\
\text { of Ekaterinburg) }\end{array}$ & & $\begin{array}{l}\text { Number of students per } 10000 \\
\text { of population, } \%\end{array}$ \\
\hline & $\begin{array}{l}1 / 0 \text { (presence of safety } \\
\text { protection system at } \\
\text { UrFU) }\end{array}$ & Safety & $\begin{array}{l}\text { Number of registered crimes per } 1000 \\
\text { of population }\end{array}$ \\
\hline & $1 / 2$ (dormitories building) & \multirow{5}{*}{ Housing facilities } & Housing supply per head, $\mathrm{m}^{2} /$ person \\
\hline & $\begin{array}{l}1 / 2 \text { (building of new } \\
\text { dormitories and corporate } \\
\text { housing) }\end{array}$ & & $\begin{array}{l}\text { Share of families in the improved housing } \\
\text { queue, } \%\end{array}$ \\
\hline & $\begin{array}{l}1 / 2 \text { (building of new } \\
\text { dormitories and corporate } \\
\text { housing) }\end{array}$ & & Renewal of housing facilities, $\%$ \\
\hline & $\begin{array}{c}1 / 0 \text { (wreckage of old } \\
\text { dormitories) }\end{array}$ & & $\begin{array}{c}\text { Share of rundown and dilapidated } \\
\text { housing, } \%\end{array}$ \\
\hline & $\begin{array}{l}2 / 2 \text { (buiding } \\
\text { of comfortable } \\
\text { dormitories) }\end{array}$ & & $\begin{array}{l}\text { Housing supply by systems of heating, } \\
\text { water facilities }\end{array}$ \\
\hline & $\begin{array}{l}2 / 2 \text { (presence of own heat } \\
\text { source) }\end{array}$ & Public utilities & $\begin{array}{l}\text { Average yearly heat supply source output, } \\
\text { thous. gkal }\end{array}$ \\
\hline & $\begin{array}{l}2 / 2 \text { (spreading of campus } \\
\text { all over the city) }\end{array}$ & Transportation & $\begin{array}{l}\text { Number of trips per } 1 \text { person on local } \\
\text { transportation yearly, thousand times }\end{array}$ \\
\hline & $\begin{array}{l}\text { 2/3 (85 small enterprises, } \\
\text { implementation of UrFU }\end{array}$ & $\begin{array}{l}\text { Production, } \\
\text { investments }\end{array}$ & $\begin{array}{l}\text { Industrial production per } 1 \text { representative } \\
\text { of economically active population (EAP), }\end{array}$ \\
\hline
\end{tabular}




\begin{tabular}{|c|c|c|}
\hline elaborations in enterprises & & thous. rub./ person. \\
\hline $\begin{array}{c}1 / 2 \text { (implementation } \\
\text { of UrFU elaborations in } \\
\text { enterprises) }\end{array}$ & & $\begin{array}{c}\text { Investments in main capital per } \\
1 \text { representative of EAP, thous. } \\
\text { rub./person }\end{array}$ \\
\hline $0 / 0$ & & $\begin{array}{l}\text { Relative share of loss-makers in a whole } \\
\text { circle of organizations, } \%\end{array}$ \\
\hline $\begin{array}{l}0 / 0 \text { (graduates registration } \\
\text { statistics in labour market } \\
\text { is absent) }\end{array}$ & Labor market & Registered unemployment, $\%$ \\
\hline $0 / 0$ & & $\begin{array}{c}\text { Market diversity (Herfindahl-Hirschman } \\
\text { index) }\end{array}$ \\
\hline $\begin{array}{c}2 / 3 \text { (UrFU is one } \\
\text { of the biggest taxpayers) }\end{array}$ & Budget & $\begin{array}{c}\text { Share of own incomes in city budget } \\
\text { incomes, } \%\end{array}$ \\
\hline $\begin{array}{c}2 / 3 \text { (average salary level } \\
\text { of UrFU is } 2 \text { times higher } \\
\text { than an average one in } \\
\text { the city) }\end{array}$ & & $\begin{array}{l}\text { Reference of organizations employees } \\
\text { salary to minimum living wage, } \%\end{array}$ \\
\hline $\begin{array}{l}\text { 2/2 (students and } \\
\text { employees incomings and } \\
\text { purchasing power growth) }\end{array}$ & $\begin{array}{l}\text { expenditures } \\
\text { of population }\end{array}$ & $\begin{array}{c}\text { Turover of retail per } 10000 \text { of population, } \\
\%\end{array}$ \\
\hline $\begin{array}{l}\text { 2/2 (students and } \\
\text { employees incomings and } \\
\text { purchasing power growth) }\end{array}$ & & $\begin{array}{c}\text { Turnover of public catering per } 10000 \\
\text { of population, } \%\end{array}$ \\
\hline $\begin{array}{l}1 / 2 \text { (UrFU elaborations } \\
\text { introduction in enterprises } \\
\text { and residential buildings) }\end{array}$ & $\begin{array}{l}\text { Production } \\
\text { ecology }\end{array}$ & $\begin{array}{l}\text { Water consumption per unit of industrial } \\
\text { production, } \mathrm{m}^{3} / \text { thous. rub. }\end{array}$ \\
\hline $\begin{array}{c}\text { 1/2(UrFU elaborations } \\
\text { introduction in } \\
\text { enterprises) }\end{array}$ & & Pollution discharge per $1 \mathrm{~km}^{2}$ of city area \\
\hline $\begin{array}{c}1 / 1 \text { (concentration } \\
\text { of students in campus) }\end{array}$ & $\begin{array}{l}\text { Environment } \\
\text { condition }\end{array}$ & Population density, person $/ \mathrm{km}^{2}$ \\
\hline $\begin{array}{l}1 / 1 \text { (boiler house } \\
\text { presence) }\end{array}$ & & Integrated air impurity index (AII) \\
\hline
\end{tabular}

In the models of entrepreneurial university, in the framework of the models considered in the article, there is a unit of indicators connected with the assessment of university influence on economics and society. It is offered to supplement them with the following groups and elements:

- scale of university influence on social, economical and ecological development of the city in measuring employment, goods and services production volume, taxation base growth, salary growth, demographic indicators improvement;

- level of impact on the indicators of innovation development, connected with the transfer of new technologies in the sphere of industry and services, development of high technological clusters, increase of innovation products output and export, increase of economics research intensity, development of labour productivity, intellectual property objects application;

- level of influence on entrepreneurial climate of the city is defined by number of small and medium enterprises, created with the help of the university, development of technical parks and business-incubators, increase of entrepreneurial culture and education level;

- level of impact on population social and ecological activity is connected with active youth policy of the university, influence on public organizations work, expert community, leading of cultural and ecological events. 
Expert assessment (according to 5 grade scale) of UrFU entrepreneurial potential in 2015 in the framework of the work model [16] with consideration of offered influence indicators is shown in picture 1 on the basis of three target expert groups cancass representatives of the university, business and authorities.

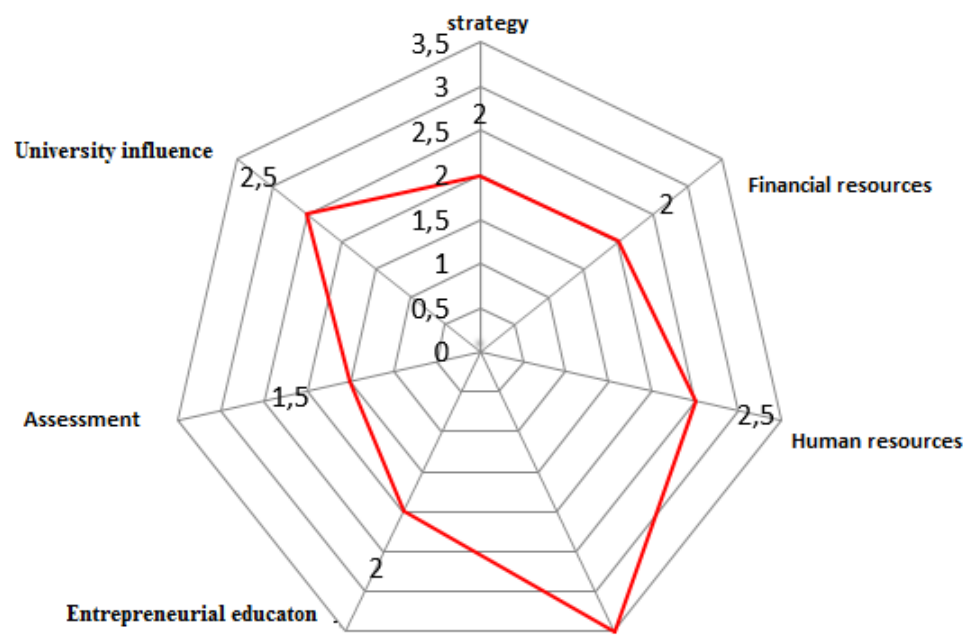

$3,5^{\text {Start ups support }}$

Fig. 1. UrFU entrepreneurial potential assessment.

Model of sustainable city development with new indicator groups offered in the article, and model of entrepreneurial university with the unit of university indicators of impact on economics and society are congruent, i.e. accounting scale and dynamics of mutual influence. Substantial disadvantage is a different nature of indicators in these models: indicative for cities and expert for universities, which requires working out indicative markers of entrepreneurial university potential development.

\section{Conclusions}

Existing models of sustainable cities development and entrepreneurial universities do not take their mutual influence into consideration and do not allow to work out inclusive strategies of competitive advantages shaping taking into account mutual opportunities.

As regards growing universities role in cities development, the work offers approaches to creation of congruent cities and universities models on the basis of the principle «wonwon», the principle of considering scale and dynamics of university activity influence on sustainable city development, systems of conjugate exponents and indicators were worked out.

For further application of this approach it is necessary to develop the system of quantitative indicators, reflecting entrepreneurial university growth, methods of their accounting and analysis, performance of cities indicators research, those cities where entrepreneurial universities are present.

\section{Acknowledgements}

This research was supported by Act 211 Government of the Russian Federation, agreement № 02.A03.21.0006 


\section{References}

1. Alvin Toffler, The Third Wave (2004)

2. Our mutual future. Report of International Committee on environment and development (1989)

3. Rio de Janeiro declaration on environment and development (1992), http://www.un.org/ru/documents/decl_conv/declarations/riodecl.shtml

4. Decree of RF President № 236 from 04.02.94, http://www.kremlin.ru/acts/bank/5422

5. LEIPZIG CHARTER on Sustainable European Cities (2007), http://ec.europa.eu/regional_policy/archive/themes/urban/leipzig_charter.pdf

6. Reference Framework for European Sustainable Cities, www.slideshare.net/RFSC

7. Concept of sustainable development of Sochi up the year 2010, http://www.sochiadm.ru/upload/iblock/aaa/aaa984be6c24cb8caecc072fb8f3dbc4.pdf

8. Indicators of Sustainable Development, UN Department for Policy Coordination and Sustainable Development, December (1994)

9. Human Development Report 2003. Millennium Development Goals: A compact among nations to end human poverty (2003), http://hdr.undp.org/sites/default/files/reports/264/hdr_2003_en_complete.pdf

10. S.N. Bobyileva, P.A. Makeenko, Indicators of Sustainable Development of Russia (ecological-economical aspects) (2001)

11. J. Houghton, P. Sheehan, A Primer on the Knowledge Economy (2000).

12. B. Clark, Journal of the Programme on Institutional Management in Higher Education, 13 (2), 9-24 (2001)

13. G.N. Konstantinov, S.R. Philonovich, Education issues, 1, 49-62 (2007)

14. S.V. Kortov, D.B. Shulgin, N.G. Terlyga, Innovations, 8 (190), $42-50$ (2014)

15. H. Etzkowitz, A. Webster, C. Gebhardt, B.R.C. Terra, Research Policy, 29 (2), 313330 (2000)

16. D. Williams, A. Kluev, Industry and Higher Education, 28(4), 271-280 (2014)

17. A. Kuzmin, G. Podolniy, Designing, monitoring and assessment, 2, 2-18 (2015)

18. New paradygm of Russia development in XXI century. Complex research of sustainable development problems: ideas and results (2000)

19. New models of cities development. View McKinsey \& Company. http://gtmarket.ru/laboratory/expertize/5974

20. Rating of sustainable cities development in RF during the year 2012 http://agencysgm.com/upload/iblock/66b/reyting_2012.pdf

21. Strategy of social-economic development in Sverdlovk region. http://smb.gov66.ru/content/legislation/regionalleg/act adm reg/m,65,1320

22. B. Clark, Higher Education Policy, 17, 355-370 (2004)

23. OECD. Universities, innovation and entrepreneurship. Criteria and examples of good practice. http://www.oecd.org/regional/leed/43201452.pdf

24. National rating of the Russian universities by Interfax agency, http://www.univerrating.ru/txt.asp?rbr=30 